\title{
Ultimate Compressive Strength and Its Deformation of Normal and High Strength Concrete Cylinder Confined With External Lateral Pre-Stressing
}

\author{
Harianto Hardjasaputra ${ }^{1}$, Joey Tirtawijaya ${ }^{1}$, Gino $\mathrm{P} . ~_{\mathrm{Ng}^{1}}$, Selvira Ayuningtias ${ }^{1}$ \\ ${ }^{1}$ Civil Engineering Department, Universitas Pelita Harapan, Tangerang, Indonesia
}

\begin{abstract}
Confining reinforcement for concrete columns have been standardized in building standards ACI 318-11 and SNI 03-2847-2013. The observation of building collapse by earthquake normally caused by malfunction of the building columns as bearing elements. The columns were failed because they did not meet the standard of confining reinforcement. In most cases, external confinement is necessary to strengthen the existing columns of old buildings. This research focused on the methods to strengthen the existing columns. Three types of pre-stressed steel rings were used to confine the concrete cylinders of $10 \mathrm{x} 20 \mathrm{~cm}$ and 10 x $30 \mathrm{~cm}$. Several concrete strengths of $50 \mathrm{MPa}, 70 \mathrm{MPa}$ and $100 \mathrm{MPa}$ were selected for constructing 18 specimens of concrete cylinders. The first type of pre-stressed is with zero pre-stressing force represented passive confinement while the second and third types were given different prestressing forces on the steel ring represented active confinement. Prestressing force on the steel ring will cause radial stress that compress the concrete cylinders. Load test were conducted on concrete cylinders to measure the strength and the relationship of stress strain concrete cylinders which was confined by varied external lateral pre-stressing. The testing results showed that the external lateral prestressing increases the ductility and strength of concrete columns. It proved the method of external lateral pre-stressing can be used effectively for retrofitting and strengthening existing columns in order to meet the requirement of ductility and strength.
\end{abstract}

\section{Introduction}

Reinforced concrete columns are widely used for high rise building constructions all over the world. Columns support high compressive forces in tall buildings. However, columns may suffer damage especially due to earthquakes, due to the limited strength and ductility of concrete. The failure of one or more columns will lead to massive building failure. Standard of confinement of reinforced concrete columns is one of the most important aspect in the earthquake resistant buildings design. Lateral confinement by means of individual ties or continuous spiral on reinforced concrete column can increase the strength and performance of the column against axial and lateral forces significantly. 
Based on ACI 318M-99 for the first time Indonesian Building Code for Structural Concrete (SNI 2837-2002) has made standard calculation for requirement of RC columns confinement. The total cross sectional of rectangular confinement bar $\mathrm{A}_{\mathrm{sh}}$ shall not be less than required by these following equations (SNI 2837-2013)

For rectangular hoop reinforcement:

$$
\begin{gathered}
A_{s h}=0,3\left(\frac{s h_{c} f_{c}^{\prime}}{f_{y h}}\right)\left[\left(\frac{A_{g}}{A_{c h}}\right)-1\right] \\
A_{s h}=0,09\left(\frac{s h_{c} f_{c}^{\prime}}{f_{y h}}\right)
\end{gathered}
$$

For circular hoop reinforcement:

$$
\rho_{\mathrm{s}}=0,12 f_{c}^{\prime} / f_{y h}
$$
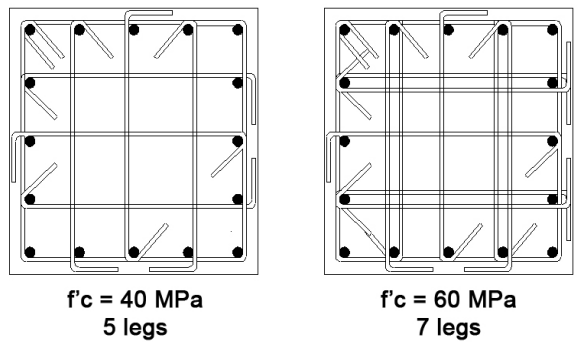

Fig. 1. Typical requirement of lateral ties of RC Columns for concrete strength $40 \mathrm{MPa}$ and $60 \mathrm{MPa}$ based on SNI 2837-2013.

The observation of building collapse caused by earthquake in Indonesia like in Padang (2009) and Yogyakarta (2006) showed that mostly the building columns were failed due to malfunction as the bearing elements. In fact most of the columns had been constructed without sufficient lateral ties to confine the RC columns and secure the ductility. The shortage of confinement provided by lateral ties was the motivation for conducting this research in finding new technique to retrofit the existing columns of the old buildings, constructed before the SNI 2837-2002 was published.

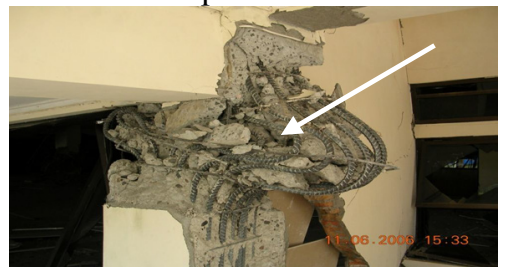

Fig. 2. Column damage due to Yogyakarta Earthquake (2006), because of the shortage of the strength and ductility.

External confinement can be done to strengthen the existing columns by using steel, reinforced concrete and fibre reinforced polymer (FRP) jacketing. With these techniques, the columns will get additional confinement strength. Those techniques have been grouped as additional passive confinement.

This paper reports a new technique of external confinement, called additional active confinement. For circular columns, the additional confinement will be delivered by the pre- 
stressed force $\mathrm{T}$ of the external steel rings, arranged around column perimeter as shows on Fig. 3.

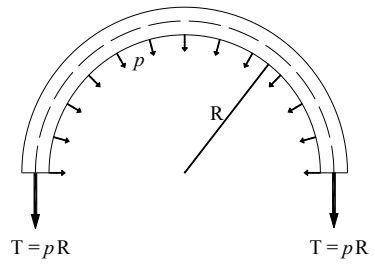

Fig. 3. The pre-stressed force $T$ generates lateral pre-stressed force $p$ at the contact surface of concrete cylinder.

The lateral pre-stressed force $\mathrm{p}$ can be calculated with equation 5 .

$$
\begin{aligned}
& T=p \cdot R \\
& \tau=\frac{\epsilon_{s} \cdot E_{s} \cdot A_{s}}{R}
\end{aligned}
$$

where,

$\varepsilon_{\mathrm{s}} \quad=$ Strain of steel ring

Es = Modulus of Elasticity of Steel Ring $(\mathrm{MPa})$

As = Area of steel ring section $\left(\mathrm{mm}^{2}\right)$

$\mathrm{R} \quad=$ Radius of cylinder $(\mathrm{mm})$

The objective of this research is to study the influence of lateral pre-stressed force $p$ to the increasing of strength and ductility of concrete cylinders created from normal and high strength concrete. Table 1 shows the loading test for 18 concrete cylinders of 10x $20 \mathrm{~cm}$ and $10 \times 30 \mathrm{~cm}$, which laterally reinforced with pre-stressed steel ring.

\begin{tabular}{|c|c|c|c|c|}
\hline No. & Code & fc' (MPa ) & $\begin{array}{c}\text { Cylinder Dimension } \\
\text { (cm) }\end{array}$ & Type of Steel Ring \\
\hline 1. & S $10 / 20-W O$ & 50.2 & $10 / 20$ & WO \\
\hline 2. & S 10/20-W1 & 50.2 & $10 / 20$ & W1 \\
\hline 3. & S 10/20-W2 & 50.2 & $10 / 20$ & W2 \\
\hline 4. & S 10/30-WO & 50.2 & $10 / 30$ & WO \\
\hline 5. & S 10/30-W1 & 50.2 & $10 / 30$ & W1 \\
\hline 6. & S 10/30-W2 & 50.2 & $10 / 30$ & W2 \\
\hline 7. & S $10 / 20-W O$ & 68,11 & $10 / 20$ & WO \\
\hline 8. & S 10/20-W2 & 68,11 & $10 / 20$ & W1 \\
\hline 9. & S 10/20-W2 & 68,11 & $10 / 20$ & W2 \\
\hline 10. & S 10/30-WO & 68,11 & $10 / 30$ & WO \\
\hline 11. & S 10/30-W1 & 68,11 & $10 / 30$ & W1 \\
\hline 12. & S 10/30-W2 & 68,11 & $10 / 30$ & W2 \\
\hline 13. & S 10/20-WO & 101,8 & $10 / 20$ & WO \\
\hline 14. & S 10/20-W1 & 101,8 & $10 / 20$ & W1 \\
\hline 15. & S $10 / 20-W 2$ & 101,8 & $10 / 20$ & W2 \\
\hline 16. & S 10/30-WO & 101,8 & $10 / 30$ & WO \\
\hline 17. & S $10 / 30-W 1$ & 101,8 & $10 / 30$ & W1 \\
\hline 18. & S 10/30-W2 & 101,8 & $10 / 30$ & W2 \\
\hline
\end{tabular}

Table 1. Type of concrete cylinder specimen.

Note: 
WO : steel ring non pre-stressed.

W1 : steel ring with moderate pre-stressed force.

W2 : steel ring with high pre-stressed force.

\section{Method of research}

\subsection{Experimental program}

Two groups of cylinder $10 \mathrm{~cm}$ x $20 \mathrm{~cm}$ and $10 \mathrm{~cm}$ x $30 \mathrm{~cm}$ were selected to produced 18 concrete specimens with concrete strength of $50 \mathrm{MPa}, 68 \mathrm{MPa}$ and $100 \mathrm{MPa}$ respectively for each cylinder group. For each group has three types of external steel rings as follows; Type W0: steel ring without pre-stressed force, Type W1: steel ring with moderate prestressed force and Type W2: steel ring with high pre-stressed force.

\subsection{Design of steel ring}

High level grade steel was used for the rings in the test specimens. According to the tension test of the steel plate shows that the yield strength of the external steel ring used in this research is $487 \mathrm{MPa}$ and its Elasticity Modulus is $185.151 \mathrm{~N} / \mathrm{mm}^{2}$. Each steel ring has 25 $\mathrm{mm}$ width and $2.4 \mathrm{~mm}$ thickness. Figure 4 shows the designs of Steel ring W0, W1 and W2. Steel ring W0 is a type of passive confinement installed to the concrete cylinder and grouted with cement paste to secure the bonding with the surface of concrete cylinder, on the other side, steel ring W1 and W2 can be grouped as type of active confinement. They were equipped with bolt to apply the lateral pre-stressed force $\mathrm{p}$ to the concrete cylinder by tightening the bolt.
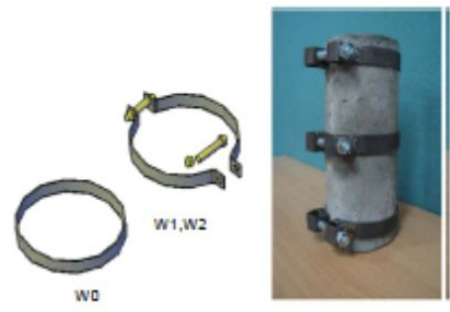

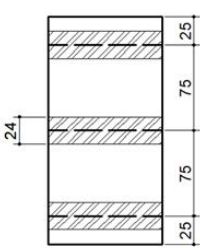

S-10/20

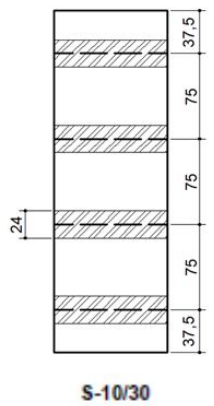

S-10/30

Fig. 4. Steel Ring design and its position at concrete cylinder.

\subsection{Concrete properties}

Portland Cement of grade 42.5 MPa conforming type 1 of Indonesian Standard (SNI 150249: 2004) was used in preparing the test specimen. Locally coarse aggregate was sieved with maximum size of $12.5 \mathrm{~mm}$, while fine aggregate was sieved with maximum size of 0.9 $\mathrm{mm}$. The concrete mixing had been designed for three kinds of concrete strength namely $\mathrm{f}_{\mathrm{c}}$ ' $50 \mathrm{MPa}$ for normal concrete and $\mathrm{f}_{\mathrm{c}}{ }^{\prime} 68 \mathrm{MPa}$ and $101 \mathrm{MPa}$ for high strength concrete. 


\subsection{Test specimens preparing}

Three steel rings were installed on each of concrete cylinder test specimen. In order to secure the same level of lateral prestressed force $\mathrm{p}$ all the steel ring W1 and W2 have to be tightened by torque wrench. The steel ring W1 was tightened with $15 \mathrm{Nm}$ force while steel ring W2 was tightened with $20 \mathrm{Nm}$ force. Strain gauge was installed on the steel ring in order to measure the stress level.

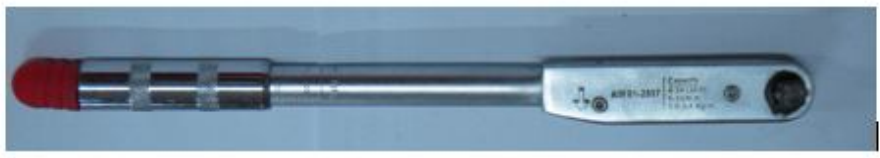

Fig. 5. Torque wrench.

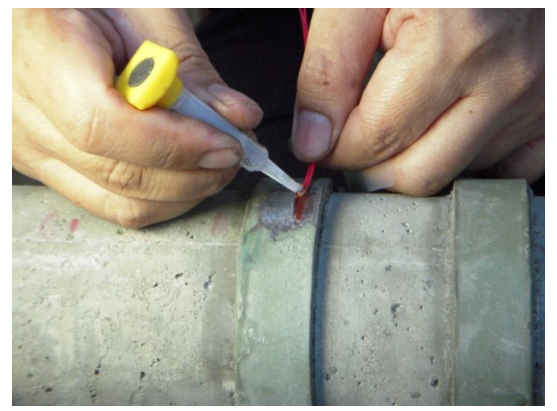

Fig. 6. Attaching strain gauge at steel ring.

The lateral pre-stressed force $\mathrm{p}$ can be determined with equation 5 based on the measured strain during tightening bolt on each steel ring W1 and W2.

Table 2. Effective lateral pre-stressed force $\mathrm{p}$ according to equation 5

\begin{tabular}{|c|l|c|c|c|c|}
\hline No. & \multicolumn{1}{|c|}{ Code } & $\begin{array}{c}\text { Dimension } \\
(\mathbf{c m})\end{array}$ & $\begin{array}{c}\text { Kind of } \\
\text { ring }\end{array}$ & $\begin{array}{c}\mathbf{\varepsilon}_{\mathrm{s}} \\
\left(\mathbf{1 0}^{-\mathbf{3}} \mathbf{\%}\right)\end{array}$ & $\begin{array}{c}\mathbf{p} \\
\mathbf{( N / m m )}\end{array}$ \\
\hline 1 & S 10/20-WO & $10-20$ & WO & 0 & 0 \\
\hline 2 & S 10/20-W1 & $10-20$ & W1 & 225.4 & 49,9 \\
\hline 3 & S 10/20-W2 & $10-20$ & W2 & 439 & 97,5 \\
\hline 4 & S10/30-WO & $10-30$ & WO & 0 & 0 \\
\hline 5 & S 10/30-W1 & $10-30$ & W1 & 246.5 & 54.8 \\
\hline 6 & S 10/30-W2 & $10-30$ & W2 & 413 & 91.7 \\
\hline
\end{tabular}

Table 1 shows the detail of 18 concrete cylinders of $10 \times 20 \mathrm{~cm}$ and $10 \times 30 \mathrm{~cm}$ which reinforced laterally with non and pre-stressed steel ring. Three pieces of steel ring were installed for each $20 \mathrm{~cm}$ height concrete cylinder and four pieces for $30 \mathrm{~cm}$ height cylinder. There were 3 groups of concrete strength of the specimen test, which consisted of concrete strength of $\mathrm{f}_{\mathrm{c}} 50 \mathrm{MPa}, 68 \mathrm{MPa}$ and $101 \mathrm{MPa}$. All test specimens were tested under axial compression until failure by load control testing machine, equipped with LVDT to measure axial deformation. 

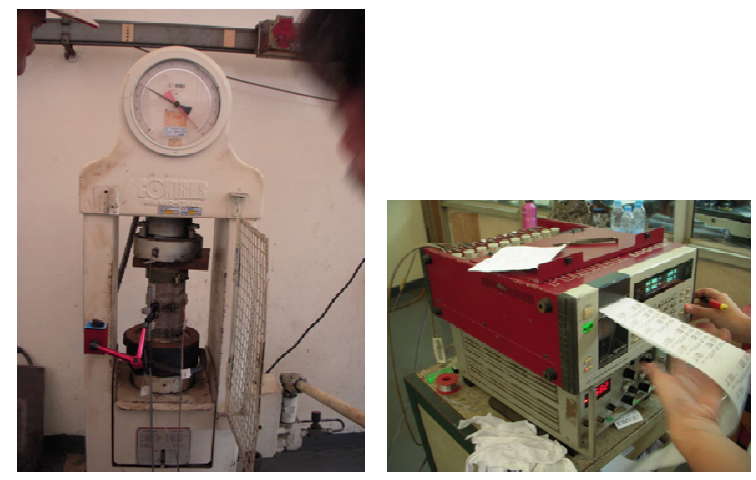

Fig. 7. Load control testing machine.

\subsection{Test result and discussion}

Experimental results of axial loading test of 18 concrete cylinders were discussed in the suceeding section. The results are compared in terms of ultimate compressive strength, axial displacement, steel ring deformation and crack propagation.

\subsubsection{Ultimate compressive strength}

All speciments have been grouped based on their compressive strength. Table 3, 4 and 5 show the loading test result of each concrete cylinder with initial compressive strength of 50.2 $\mathrm{MPa}, 68 \mathrm{MPa}$ and $101 \mathrm{MPa}$.

In general all specimens equiped with lateral steel ring W0, W1 and W2 significantly higher ultimate compressive strength than their initial concrete strength. Comparing to the table 1, table 2 and table 3 show that the biggest increment procentage of compressive strength happened for concrete cylinders with $\mathrm{f}_{\mathrm{c}} 50.2 \mathrm{MPa}$. Table 1 shows, the lateral prestressed force $\mathrm{p}$ of $97.5 \mathrm{~N} / \mathrm{mm}$ can increase the compressive strength up to $59.8 \%$. higher than its initial compressive strength.

Table 3. Concrete Cylinder with compressive strength 50.2 MPa.

\begin{tabular}{|c|c|c|c|c|c|c|}
\hline No. & Specimen & $\begin{array}{c}\mathbf{f c}, \\
\text { (MPa })\end{array}$ & $\begin{array}{c}\text { Cylinder } \\
\text { Dimension } \\
\mathbf{( c m )}\end{array}$ & $\begin{array}{c}\text { Lateral pre- } \\
\text { stressed } \\
\mathbf{( N / m m )}\end{array}$ & $\begin{array}{c}\text { Ultimate } \\
\text { compressive } \\
\text { Strength } \\
\mathbf{( M p a )}\end{array}$ & $\begin{array}{c}\text { Increasing of } \\
\text { compressive } \\
\text { strength } \\
\mathbf{( \% )}\end{array}$ \\
\hline 1 & S 10/20-WO & 50.2 & $10-20$ & 0 & 63.7 & 26.89 \\
\hline 2 & S 10/20-W1 & 50.2 & $10-20$ & 49.9 & 72.61 & 44.64 \\
\hline 3 & S 10/20-W2 & 50.2 & $10-20$ & 97.5 & 80.25 & 59.8 \\
\hline 4 & S 10/30-WO & 50.2 & $10-30$ & 0 & 57.32 & 14.5 \\
\hline 5 & S 10/30-W1 & 50.2 & $10-30$ & 54.8 & 68.7 & 19.8 \\
\hline 6 & S 10/30-W2 & 50.2 & $10-30$ & 91.7 & 70.06 & 22.23 \\
\hline
\end{tabular}


Table 4. Concrete Cylinder with compressive strength $68.1 \mathrm{MPa}$.

\begin{tabular}{|c|c|c|c|c|c|c|}
\hline No. & Specimen & $\begin{array}{c}\text { fc' } \\
\text { (MPa })\end{array}$ & $\begin{array}{c}\text { Cylinder } \\
\text { Dimension } \\
\mathbf{( c m )}\end{array}$ & $\begin{array}{c}\text { Lateral pre- } \\
\text { stressed } \boldsymbol{p} \\
\mathbf{( N / m m )}\end{array}$ & $\begin{array}{c}\text { Ultimate } \\
\text { compressive } \\
\text { Strength } \\
\mathbf{( M p a )}\end{array}$ & $\begin{array}{c}\text { Increasing of } \\
\text { compressive } \\
\text { strength } \\
\mathbf{( \% )}\end{array}$ \\
\hline 1 & S 10/20-WO & 68.1 & $10-20$ & 0 & 79.61 & 16.9 \\
\hline 2 & S 10/20-W1 & 68.1 & $10-20$ & 49.9 & $76^{*}$ & 11.6 \\
\hline 3 & S 10/20-W2 & 68.1 & $10-20$ & 97.5 & 101.9 & 49.63 \\
\hline 4 & S 10/30-WO & 68.1 & $10-30$ & 0 & 73.24 & 7.55 \\
\hline 5 & S 10/30-W1 & 68.1 & $10-30$ & 54.8 & 82.8 & 21.59 \\
\hline 6 & S 10/30-W2 & 68.1 & $10-30$ & 91.7 & 92.35 & 35.61 \\
\hline
\end{tabular}

*Failure due to bolt damage.

Table 5. Concrete Cylinder with compressive strength $101 \mathrm{MPa}$.

\begin{tabular}{|c|c|c|c|c|c|c|}
\hline No. & Specimen & $\begin{array}{c}\text { fc' } \\
\text { (MPa ) }\end{array}$ & $\begin{array}{l}\text { Cylinder } \\
\text { Dimension } \\
\text { (cm) }\end{array}$ & $\begin{array}{c}\text { Lateral } \\
\text { pre- } \\
\text { stressed p } \\
(\mathrm{N} / \mathrm{mm})\end{array}$ & $\begin{array}{c}\text { Ultimate } \\
\text { compressive } \\
\text { Strength } \\
\text { (Mpa) }\end{array}$ & $\begin{array}{l}\text { Increasing of } \\
\text { compressive } \\
\text { strength } \\
(\%)\end{array}$ \\
\hline 1 & S $10 / 20-W O$ & 101.8 & 20 -Oct & 0 & 124.2 & 22 \\
\hline 2 & S 10/20-W1 & 101.8 & 20-Oct & 49.9 & 130 & 27.7 \\
\hline 3 & S 10/20-W2 & 101.8 & 20-Oct & 97.5 & $116^{*}$ & 13.95 \\
\hline 4 & S $10 / 30-W O$ & 101.8 & 30-Oct & 0 & 114 & 11.98 \\
\hline 5 & S 10/30-W1 & 101.8 & $30-$-Oct & 54.8 & 117.2 & 15.13 \\
\hline 6 & S 10/30-W2 & 101.8 & 30-Oct & 91.7 & $111.5 *$ & 9.53 \\
\hline
\end{tabular}

*Failure due to bolt damage.

The resutls show the effectiveness of lateral prestessed force p. Specimens reinforced with steel rings $\mathrm{W} 1$ and $\mathrm{W} 2$ show higher compressive strength than specimens reinforced with steel rings W0. Fig 8 and Fig 9 show the summary of the influence of steel ring W0, $\mathrm{W} 1$ and $\mathrm{W} 2$ versus the ultimate compressive strength of each specimen. 
Concrete Cylinder 10-20

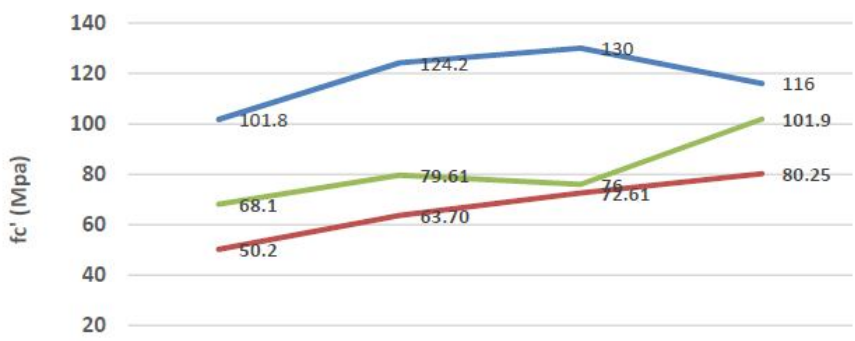

\begin{tabular}{|c|c|c|c|c|}
\hline 0 & $\mathrm{fc}^{\prime}$ & WO $(0 \mathrm{~N} / \mathrm{mm})$ & W1 $(49.9 \mathrm{~N} / \mathrm{mm})$ & W2 $(97.5 \mathrm{~N} / \mathrm{mm})$ \\
\hline-50.2 & 50.2 & 63.70 & 72.61 & 80.25 \\
\hline 68.1 & 68.1 & 79.61 & 76 & 101.9 \\
\hline 101.8 & 101.8 & 124.2 & 130 & 116 \\
\hline
\end{tabular}

$-50.2-68.1-101.8$

Fig. 8. Graphic and table of ultimate concrete strength increment.

Concrete Cylinder 10-30

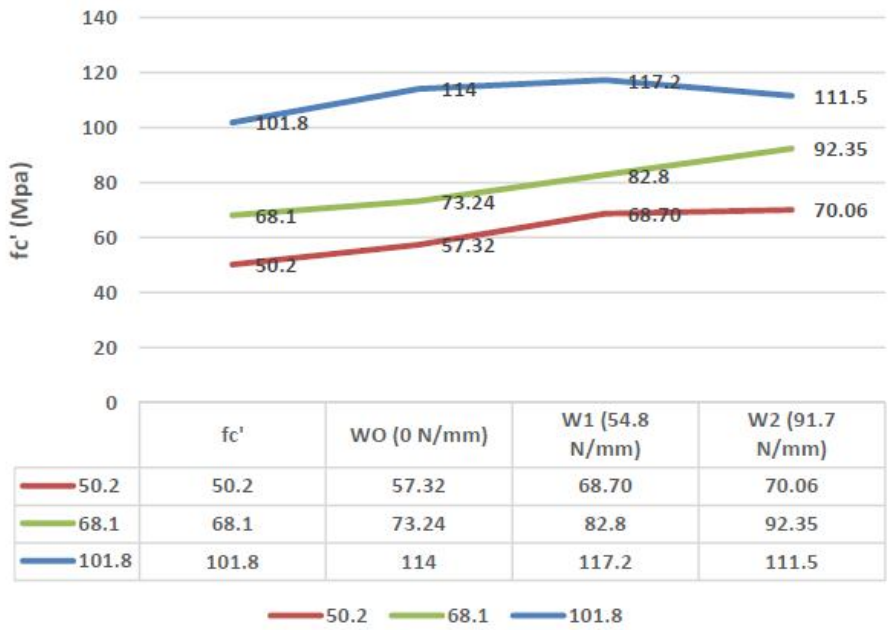

Fig. 9. Graphic and table of ultimate concrete strength increment.

\subsubsection{Concrete strain}

Alike ultimate compressive strength, all concrete cylinder specimens equiped with lateral steel ring $\mathrm{W} 0, \mathrm{~W} 1$ and $\mathrm{W} 2$ show higher ultimate axial strain, i.e axial ductility. 


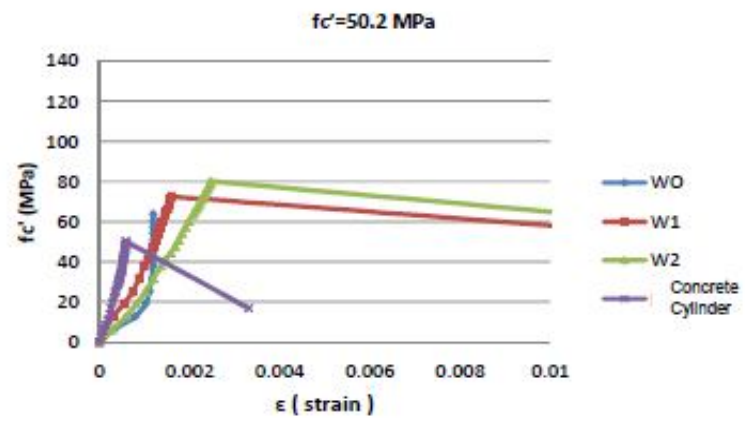

Fig. 10. Stress-Strain of concrete specimens with $\mathrm{f}_{\mathrm{c}}^{\prime} 50.2 \mathrm{MPa}$.

\subsubsection{Crack Pattern}

Typical failure crack pattern of each concrete cylinder specimen was shown in figure 11 for cylinder height $20 \mathrm{~cm}$ and Fig 12 for cylinder height $30 \mathrm{~cm}$. They show that although the ultimate compressive strength was very high, all the specimens could keep their form at the failure. It can be concluded, that lateral steel rings can avoid brittle failure of concrete, especially high strength concrete.

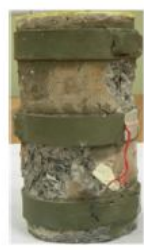

wo

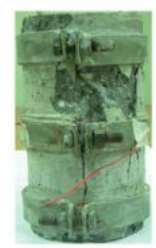

W1

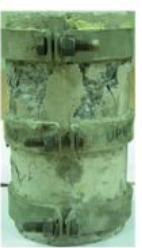

W2

Fig. 11. Crack pattern of concrete cylinder S-10/20.

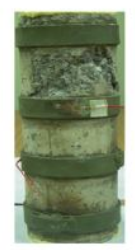

Wo

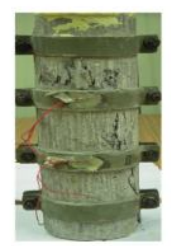

W1

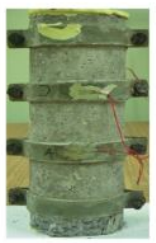

W2

Fig. 12. Crack pattern of concrete cylinder S-10/30.

\section{Conclusion}

Based on the result of loading test of 18 concrete cylinder specimens in can be concluded that:

1. Confining with Lateral steel ring can improve the ultimate compressive strength effectively including their ultimate axial strain of concrete. The percentage of compressive strength increment for normal concrete is much higher than high strength concrete.

2. Specimens with Lateral steel ring pre-stressed (W1 and W2) have higher compressive strength than specimens with lateral steel ring non pre-stressed (W0). it 
shows the effectiveness of lateral pressure force $\mathrm{p}$ in improving the strength and ductility.

3. The comparison of steel ring W1 and W2 show the magnitude of lateral pressure force $p$ influences the percentage of strength increment of concrete.

4. Specimens with high strength concrete $\mathrm{f}_{\mathrm{c}}{ }^{\prime} 101.8 \mathrm{MPa}$ show lower percentage of compressive strength increment than normal concrete $f_{c}^{\prime} 50$. Therefore, to confining high strength concrete cylinder, high grade steel ring is mandatory.

The first Author would like to acknowledge that some part of this paper has been written during his research visit at Uni-Kassel and TU Berlin in Germany, granted by Konrad Adenauer Stiftung.

\section{References}

1. Hardjasaputra, Harianto, T. Joey, S. Ayungtiniyas, "Perilaku Hubungan Tegangan Regangan Beton Silinder Yang Dikekang External Lateral Prestress [Stress Strain Relation of Concrte Cylinder Confined with External Lateral Pre-stressed]", Research Report No.: P-007-FDTP/II/2009, Universitas Pelita Harapan, Indonesia.

2. A.B.M. Amrul Kaish, M. R. Alam, M. Jamil, M. A. Wahed, Ferrocement Jacketing for Restrengthening of Square Reinforced Concrete Column under Cocentric Compressive Load, Procedia Engineering 54, 720-728, (2013)

3. König, V. Tue and Zink. Hochleistungbeton. Germany: Wiley-VCH, 2001 Building Code Requirements for Structural Concrete (ACI 318M-11) Structural Concrete Requirements for Buildings - Indonesian National Standard (SNI 2847-2013)

4. H.E.H. Roy, and M.A. Sozen, 'Ductility of concrete' in 'Flexural Mechanics of Reinforced Concrete', SP-12 (ACI/American Society of Civil Engineers, Detroit, 1965) 213-224.

5. K. Wight MacGregor, Reinforced Concrete Mechanics and Design, 4th ed. Singapore: Prentice Hall, (2008)

6. M.T. Soliman, and C.W. Yu, "The Flexural Stress Strain Relationship of Concrete Confined by Rectangular transverse Reinforcement." Mag of Concrete Research , 61, No. 19, 223 - 238, (1967)

7. J.B. Mander, M.J.N. Priestley, and R.F. Park, "Theoretical stress-strain model for confined concrete", J. Struct. Engrg., ASCE 114 (8), 1804-1826, (1988)

8. M. Cem. "Retrofitting Existing Concrete Columns by External Prestressing." U.S.Patent 6, 247, 279 B1 (2001)

9. L. Burns. Design of Prestressed Concrete Structures, 3rd ed. New York: John Wiley \& Sons, (1982) 